\title{
Inside the psychopathic mind : social cognition, emotional experience, and affect regulation in psychopathy
}

Citation for published version (APA):

Nentjes, L. (2015). Inside the psychopathic mind : social cognition, emotional experience, and affect regulation in psychopathy. [Doctoral Thesis, Maastricht University]. Maastricht University. https://doi.org/10.26481/dis.20150622ln

Document status and date:

Published: 01/01/2015

DOI:

10.26481/dis.20150622In

Document Version:

Publisher's PDF, also known as Version of record

Please check the document version of this publication:

- A submitted manuscript is the version of the article upon submission and before peer-review. There can be important differences between the submitted version and the official published version of record.

People interested in the research are advised to contact the author for the final version of the publication, or visit the DOI to the publisher's website.

- The final author version and the galley proof are versions of the publication after peer review.

- The final published version features the final layout of the paper including the volume, issue and page numbers.

Link to publication

\footnotetext{
General rights rights.

- You may freely distribute the URL identifying the publication in the public portal. please follow below link for the End User Agreement:

www.umlib.nl/taverne-license

Take down policy

If you believe that this document breaches copyright please contact us at:

repository@maastrichtuniversity.nl

providing details and we will investigate your claim.
}

Copyright and moral rights for the publications made accessible in the public portal are retained by the authors and/or other copyright owners and it is a condition of accessing publications that users recognise and abide by the legal requirements associated with these

- Users may download and print one copy of any publication from the public portal for the purpose of private study or research.

- You may not further distribute the material or use it for any profit-making activity or commercial gain

If the publication is distributed under the terms of Article $25 \mathrm{fa}$ of the Dutch Copyright Act, indicated by the "Taverne" license above, 


\section{Stellingen behorende bij het proefschrift}

\section{Inside the psychopathic mind}

\section{Social cognition, emotional experience, and affect regulation in psychopathy}

1. Omdat psychopathische mensen regelmatig in onveilige omgevingen verkeren, hebben ze een realistische en functionele kijk op de vijandige motieven van anderen (deze thesis).

2. Onder bepaalde omstandigheden kunnen psychopathische mensen echte emoties voelen en laten zien (deze thesis).

3. De levensstijl/gedragsmatige trekken van psychopathie vormen een integraal onderdeel van deze stoornis. Om een compleet beeld te kunnen krijgen van de emotionele afwijkingen die psychopathie typeren, is het daarom van groot belang om zowel de interpersoonlijke/affectieve symptomen als de antisociale kenmerken van psychopathie in ogenschouw te nemen (deze thesis).

4. Onderzoek dat focust op hoe psychopathische mensen zichzelf en anderen zien is nuttiger voor het generen van verklaringen voor hun antisociale gedrag dan onderzoek dat focust op een gebrek aan angst (deze thesis).

5. De psychopaat, de borderliner en de narcist bestaan niet, ieder mens bezit tot op zekere hoogte psychopathologische trekken. De categorisering van mensen met en zonder stoornis zou daarom moeten worden afgeschaft in de forensische praktijk.

6. De groeiende nadruk op innovatie ten opzichte van replicatie in de wetenschap bedreigt onze wetenschappelijke kennisfundering.

7. Ons huidige justitiële systeem is er niet op ingericht om onze wetenschappelijke kennis over forensische psychopathologie en de behandeling hiervan optimaal te bevorderen, met alle schadelijke gevolgen van dien.

8. Toegepast onderzoek verdient geen prioriteit ten opzichte van fundamenteel onderzoek, ook niet wanneer het fenomenen betreft die zo'n desastreuze maatschappelijke invloed hebben als psychopathie. 